\title{
JUURNAL_RU
}

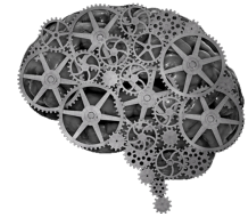

COMPANY GROUP "INTELLEKT"

\author{
Кулакова А.Б. \\ Институт социиально-экономического развития территорий \\ Российской академии наук \\ Вологда, Россия
}

doi: 10.18411/1j2016-3-22

\section{Научно-исследовательская деятельность как компонент формирования интеллектуального потенциала региона}

Одной из главнейших задач развития потенциала научно-технического комплекса страны является создание условий для привлечения и закрепления талантливой молодежи в сфере науки, формирование системы непрерывной подготовки кадров высокой квалификации, начальным этапом которой является организация научно-исследовательской деятельности в школе. В связи с этим необходимо создать для молодежи новою среду - научные исследования, изучение методов исследовательской и проектной деятельности по разным направлениям. Поиск данного решения в процессе организации научноисследовательской работы является одним из компонентов функционирования Научно-образовательного центра экономики и информационных технологий ИСЭРТ РАН (далее НОЦ ИСЭРТ РАН). Практика организации научноисследовательской деятельности в нем осуществляется по нескольким направлениям: преподавание элективного курса «Основы исследовательской деятельности» в 8 - 10 классах экономического факультатива; организация участия школьников в конкурсах научно-исследовательских работ и эссе НОЦ ИСЭРТ РАН; привлечение обучающихся к участию во внешних конкурсах, конференциях и олимпиадах; стимулирование участия студентов в исследовательских проектах, реализуемых научными отделами ИСЭРТ РАН; 
организация участия аспирантов и молодых ученых в научно-исследовательской деятельности. В Научно-образовательном центре ИСЭРТ РАН за период с 2003 по 2015 гг. проведено 12 конкурсов научно-исследовательских работ среди обучающихся среднего и старшего звена НОЦ, 14 подобных мероприятий среди студентов, аспирантов и молодых ученых региона, выпущено 25 сборников, включающих в себя материалы исследований призеров конференций.

Участие в конкурсах научно-исследовательских работ (НИР) и эссе по экономике помогает вовлечь обучающихся в исследовательскую работу и способствует более эффективному усвоению знаний в области экономики, развитию способностей, профориентации. Так, на протяжении 2002/03 - 2014/15 уч. гг. для ребят $5-8$ классов проводится конкурс эссе, а для обучающихся $9-$ 11 классов - конкурс научно-исследовательских работ по экономике. За данный период в научно-исследовательскую деятельность было вовлечено более 1000 школьников. За прошедшие 13 лет обучающимися подготовлено 402 научноисследовательских работы и 425 эссе. Динамика количества работ школьников, представленных на конкурсы в 2002/03 - 2014/15 уч. гг. представлена на рисунке 1.

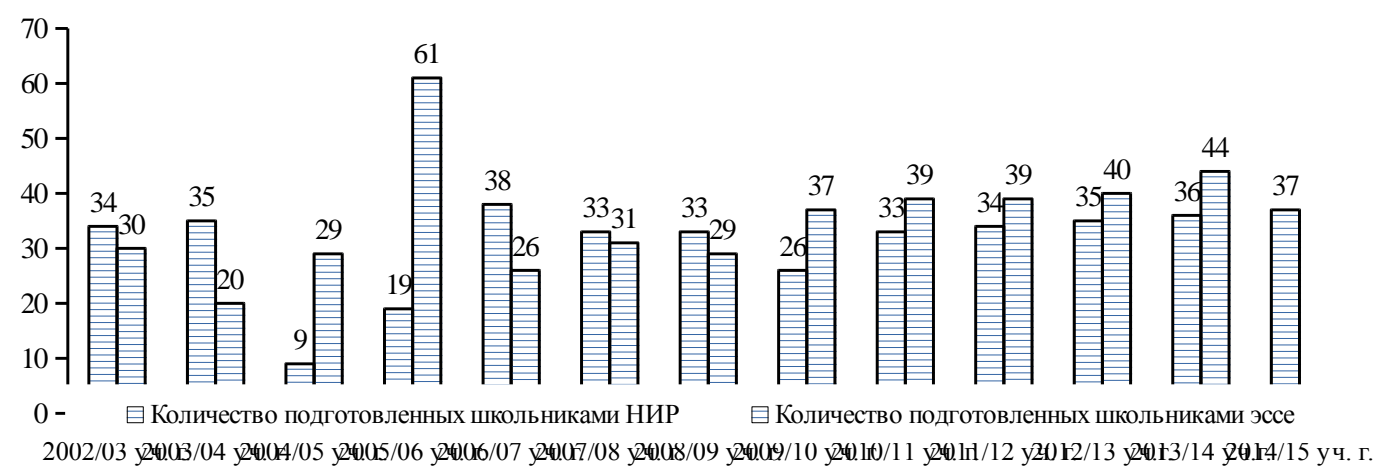

Рис. 1. Динамика количества работ школьников, представленных на конкурсы

НИР и эссе в 2002/03 - 2014/15 уч. гг. (шт.)

Научными руководителями обучающихся выступают аспиранты и научные сотрудники ИСЭРТ РАН. Они оказывают помощь обучающимся в выборе темы исследования, определении объекта и предмета, разработке 
структуры научной работы. Лучшие работы публикуются в сборнике «Экономика региона глазами старшеклассников».

Таким образом, современные технологии и социальные требования призывают формировать новое общество, способное к применению инновационных разработок, продуктивной деятельности в различных областях, анализу информации различного содержания и т. д. Все эти навыки формируются в русле исследовательской работы, а значит, опыт Научнообразовательного центра в данной деятельности является востребованным и социально значимым.

\section{Литература:}

1. Сеничева, Н.Н. Участие обучающихся в конкурсах и олимпиадах как форма работы со школьниками, склонными к изучению предмета (на примере НОЦ ИСЭРТ РАН) [Текст] / Н.Н. Сеничева // Перспективные инновации в науке, образовании, производстве и транспорте - 2014: - сб. материалов Междунар. науч.-практ. Интернет-конф. 16 - 26 декабря 2014 г.: Одесса.

2. Фомина, Ж.В. Исследовательская деятельность обучающихся в формировании ключевых компетенций [Текст] / Ж.В. Фомина, А.Б. Кулакова, Д.В. Соколова // В мире научных открытий. - 2015. - № 1.1 (76). - C. 693-703. 